\title{
Identifikasi Problematika Evaluasi Pendidikan Karakter di Sekolah
}

\author{
Das Salirawati ${ }^{1, *}$ \\ ${ }^{1} J u r u s a n$ Pendidikan Kimia, Fakultas Matematika dan IImu Pengetahuan Alam, Universitas Negeri \\ Yogyakarta, Kampus Karangmalang, Yogyakarta 55281 \\ *email korespondensi: das salirawati@uny.ac.id
}

Received : 12 Desember 2020; Revised : 24 Januari 2021; Accepted : 24 Februari 2021; Published : 1 April 2021

\begin{abstract}
ABSTRAK
Pencanangan pendidikan karakter telah dimulai sejak 10 tahun Ialu. Namun, hasil pelaksanaanya di sekolah belum diketahui secara pasti, sehingga diperlukan identifikasi mengenai problematika evaluasi pendidikan karakter di sekolah. Artikel ini bersifat deskriptif mengenai identifikasi bagaimana cara mengevaluasi keberhasilan pendidikan karakter di sekolah dengan tepat, sehingga nilai-nilai karakter tersebut secara nyata terinternalisasi dalam jiwa anak didik, tertampilkan dalam perilaku yang baik, dan akhirnya muncul sebagai habit (kebiasaan) yang membudaya. Beberapa faktor penyebab tidak berhasilnya implementasi pendidikan karakter sampai saat ini adalah (1) belum adanya model evaluasi pendidikan karakter sebagai pedoman operasional dalam melakukan evaluasi pendidikan karakter peserta didik secara tepat, efisien dan efektif, (2) pendidikan terlalu menekankan pada aspek intelektual sebagai ukuran keberhasilan, sehingga pembentukan karakter yang baik terabaikan, (3) tidak adanya penerapan pendidikan karakter secara menyeluruh, melainkan sekedar memenuhi kewajiban mengajar, tanpa mengetahui bagaimana seharusnya, (4) anak belum mendapatkan model yang dapat menjadi teladan, dan (5) derasnya informasi yang diterima anak tanpa penyaring. Beberapa langkah evaluasi pendidikan karakter yang diusulkan untuk mengatasi masalah utama evaluasi pendidikan karakter adalah (1) mendefinisikan atau memberi makna secara khusus pada karakter yang akan dicapai, (2) elaborasi terhadap substansi makna yang terkandung dalam karakter tersebut melalui suatu hierarki perilaku: moral knowing, moral feeling, dan moral action, (3) menyusun indikator hasil belajar yang harus dikuasai oleh anak sesuai tahap perkembangannya, (4) menjabarkan indikator karakter menjadi indikator penilaian dalam bentuk rubrik.
\end{abstract}

Kata-kata kunci: evaluasi; pendidikan karakter; problematika karakter

\section{PENDAHULUAN}

Sebagai bangsa yang berbudaya dan memiliki falsafah/pandangan hidup yang diyakini kebenarannya sampai saat ini, bangsa Indonesia mulai menyadari pentingnya akhlak mulia diutamakan dalam proses pendidikan (Yuliana, 2000). Hal ini tercermin dalam UU RI No 20/2003 tentang Sistem Pendidikan Nasional (Sisdiknas) dimana pada Pasal 3 dinyatakan bahwa pendidikan nasional bertujuan untuk mengembangkan potensi peserta didik agar menjadi manusia yang beriman dan bertakwa kepada Tuhan Yang Maha Esa, berakhlak mulia, sehat, berilmu, cakap, kreatif, mandiri, dan menjadi warga negara yang demokratis serta bertanggung jawab. Jadi yang diutamakan dalam pendidikan adalah pembentukan manusia Indonesia yang beriman dan bertaqwa, berakhlak mulia, baru kemudian menjadikan berilmu, cakap, dan kreatif. Bangsa Indonesia telah menyadari bahwa hanya mereka yang memiliki iman dan taqwa serta akhlak mulia yang baik yang dapat dididik menjadi peserta didik yang mudah diarahkan dan berhasil, sehingga akan terbentuk generasi penerus bangsa yang berkarakter dan berkualitas akhlaknya sekaligus cerdas intelektualnya (Salirawati, 2012).

Pendidikan karakter harus menjadi prioritas utama dalam dunia pendidikan saat ini, mengingat banyak permasalahan yang timbul justru dilakukan oleh beberapa pelajar di negeri ini, seperti fenomena "kecanggihan" mencontek, tawuran antar pelajar, dan kejadian-kejadian lain yang tidak mencerminkan perilaku seorang yang terpelajar (Soedarsono, 2013). Bahkan saat ini cara berbicara dan berperilaku santun anak didik terhadap guru atau orang tuanya juga semakin memprihatinkan dan sudah dalam tingkat yang mengkhawatirkan (Palunga \& Marzuki, 2017).

Pendidikan karakter bangsa merupakan tanggungjawab berbagai pihak, seperti orang-tua, sekolah, masyarakat, dan Negara (Ryan \& Lickona, 1992). Pihak mana yang tanggung-jawabnya terhadap pendidikan karakter lebih besar, tergantung pada sistem pendidikan, situasi, hukum suatu negara, dan kedewasaan 
warga masyarakat (Suparno, 2012). Sekolah sebagai institusi pendidikan formal harus dapat membantu mengantisipasi arus globalisasi yang datang, terutama hal-hal yang berkaitan dengan penanaman karakter bagi anak didiknya. Kepribadian bangsa Timur yang terkenal santun dan berbudi luhur harus dipertahankan di tengah-tengah arus globalisasi yang tak terbendung. Hal inilah yang mendasari munculnya ide kurikulum disisipi dengan penanaman nilai-nilai karakter, bukan saja bagi mata pelajaran Pendidikan Agama dan PPKn, tetapi untuk semua mapel, meskipun melalui indirect learning (Hanum \& Annas, 2019).

Guru di era globalisasi dituntut untuk dapat membekali peserta didik dengan nilai-nilai karakter terpuji yang tidak cukup hanya disampaikan, tetapi melalui pembiasaan dan keteladanan (Munawwaroh, 2019). Hal ini karena berbagai kemajuan di era modern saat ini sangat mudah mempengaruhi dan menggeser nilai-nilai karakter yang baik dari anak didik menjadi karakter yang tidak sesuai lagi dengan budaya ketimuran. Dengan kata lain, tugas guru tidak cukup hanya transfer of knowledge, tetapi juga transfer of value dan transfer of skill. Dengan demikian tujuan pendidikan nasional untuk mewujudkan manusia Indonesia seutuhnya melalui olah hati, olah pikir, olah rasa, dan olah raga agar anak didik memiliki daya saing dalam menghadapi tantangan global akan tercapai (Sulistiani \& Sukarman, 2020).

Pelaksanaan pendidikan karakter telah berjalan di setiap sekolah sejak 10 tahun terakhir (Ritonga et al., 2020). Namun hasil pelaksanaan pendidikan karakter secara konkrit tidak dapat diketahui secara pasti, kecuali hanya melalui laporan resmi dalam raport peserta didik (Purandina \& Winaya, 2020). Beberapa faktor penyebab tidak berhasilnya implementasi pendidikan karakter sampai saat ini adalah (1) belum adanya model evaluasi pendidikan karakter sebagai pedoman operasional dalam melakukan evaluasi pendidikan karakter peserta didik secara tepat, efisien dan efektif (Darmayanti \& Wibowo, 2014), (2) pendidikan terlalu menekankan pada aspek intelektual sebagai ukuran keberhasilan, sehingga pembentukan karakter yang baik terabaikan (Fakhruddin, 2014), (3) tidak adanya penerapan pendidikan karakter secara menyeluruh, melainkan sekedar memenuhi kewajiban mengajar, tanpa mengetahui bagaimana seharusnya (Zuchdi, 2010), (4) anak belum mendapatkan model yang dapat menjadi teladan, dan (5) derasnya informasi yang diterima anak tanpa penyaring (Guntur \& Aslinda, 2017). Tulisan ini akan menjawab pertanyaan: (a) apa saja problematika penerapan pendidikan karakter di sekolah?, dan (b) bagaimana langkah-langkah melakukan evaluasi pendidikan karakter di sekolah dengan tepat, sehingga nilai-nilai karakter tersebut secara nyata terinternalisasi dalam jiwa anak didik, tertampilkan dalam perilaku yang baik, dan akhirnya muncul sebagai habit (kebiasaan) yang membudaya?

\section{EKSPERIMEN}

\section{Jenis Penelitian}

Tujuan penelitian ini adalah menganalisis problematika implementasi pendidikan karakter dan merumuskan langkah-langkah pemecahannya. Sehingga penelitian ini merupakan jenis penelitian kualitatif dengan pendekatan deskriptif. Analisis kualitatif deskriptif merupakan metode penelitian yang meliputi kegiatan menganalisis, menggambarkan, dan mensintesis berbagai kondisi dan situasi dari berbagai data yang dikumpulkan (Sukmadinata, 2005). Jenis penelitian ini sering digunakan untuk meneliti kondisi objek yang alamiah, berkembang apa adanya, tidak dimanipulasi oleh peneliti, dan peneliti merupakan instrument kunci. Analisis deskriptif ini memusatkan perhatian pada pemecahan masalah aktual yang dihadapi pendidik (guru) yaitu cara untuk mengevaluasi keberhasilan pendidikan karakter di sekolah dengan tepat, sehingga nilai-nilai karakter tersebut secara nyata terinternalisasi dalam jiwa anak didik, tertampilkan dalam perilaku yang baik, dan akhirnya muncul sebagai habit (kebiasaan) yang membudaya.

\section{Waktu dan Tempat Penelitian}

Penelitian ini merupakan hasil dari proses panjang penulis dalam melakukan penilaian karakter dari 10 tahun terkahir sejak pertama dicanangkannya pendidikan karakter sebagai dosen Pendidikan Kimia di Universitas Negeri Yogyakarta.

\section{Analisis Data}

Model analisis data yang digunakan dalam penelitian ini adalah analisis deskriptif kualitatif dengan langkah-langkah: (a) Mengumpulkan data dari studi literatur dan observasi langsung mengenai problematika evaluasi pendidikan karakter di sekolah, (b) mengidentifikasi masalah yang ditemukan, (c) 
menyusun rancangan penyelesaian masalah, (d) melakukan revisi, dan (e) memberikan rekomendasi atas implementasi evaluasi pendidikan karakter melalui langkah-langkah yang perlu dilakukan dalam melakukan evaluasi pendidikan karakter.

\section{HASIL DAN DISKUSI}

\section{Konsep Karakter}

Terdapat empat istilah yang memiliki kemiripan arti dengan karakter, yaitu nilai, norma, etika, dan moral. Nilai diartikan sebagai sifat-sifat atau hal-hal penting/berguna bagi kemanusiaan atau sesuatu yang berharga bagi kehidupan manusia (KBBI, 2008). Nilai bersifat abstrak, hanya dapat dipikirkan, dipahami, dan dihayati. Empat sumber nilai dan empat jenis nilai dapat bersumber dari: (1) rasio: jenis nilai benarsalah (nilai hukum); (2) kehendak: jenis nilai baik-buruk (nilai moral); (3) perasaan: jenis nilai indah-tidak indah (nilai estetika); dan (4) agama: jenis nilai religius-tidak religius (nilai agama).

Norma merupakan ukuran, garis pengarah, atau aturan kaidah bagi pertimbangan dan penilaian atau aturan mengenai cara bertingkah laku dalam kehidupan manusia. Norma bersumber dari nilai dan berisi perintah atau larangan. Etika dan moral sering diartikan sama, namun terdapat perbedaan antara keduanya: etika (ilmu) mempunyai arti lebih luas daripada moral (ajaran) etika adalah ilmu yang mempelajari tentang hal yang baik dan hal yang buruk. Moral adalah ajaran tentang baik-buruk yang diterima umum mengenai tingkah laku atau perbuatan, sikap, kewajiban, dan sebagainya; akhlak, budi pekerti, susila (KBBI, 2008). Moral mengacu pada baik buruknya manusia sebagai manusia, bukan manusia sebagai pelaku peran tertentu dan terbatas. Dapat terjadi seorang guru bermoral jujur, tetapi berperilaku kurang baik dalam mengajar. Etika dan moral bersumber pada norma, dan norma bersumber pada nilai. Etika bersifat ilmiah (struktur kehidupan), sedang moral bersifat aplikatif (bagaimana manusia harus hidup). Nilai-nilai yang dianut seseorang bersumber pada kepribadian orang yang bersangkutan. Kejujuran adalah suatu nilai, larangan menipu atau larangan berbohong adalah norma kejujuran, dan tidak menipu atau tidak berbohong adalah moral kejujuran.

Istilah nilai sama dengan istilah karakter atau tabiat. Nilai terdiri atas sejumlah sikap dan sejumlah nilai menyusun kepribadian seseorang. Nilai luhur artinya nilai yang sangat baik, nilai luhur bangsa Indonesia adalah kumulasi nilai suku-suku bangsa Indonesia. Nilai luhur suku bangsa Indonesia merupakan kumulasi dari nilai perorangan penduduk Indonesia. Warga negara Indonesia memperoleh pendidikan nilai/karakter melalui pendidikan, pemuka agama, pemuka adat, pemuka pemerintahan, dan sebagainya. Karakter adalah nilai-nilai yang melandasi perilaku manusia berdasarkan norma agama, kebudayaan, hukum/konstitusi, adat istiadat, dan estetika. Pendidikan karakter dimaknai sebagai pendidikan nilai, pendidikan budi pekerti, pendidikan moral, pendidikan watak, yang tujuannya mengembangkan kemampuan peserta didik untuk memberikan keputusan baik-buruk, memelihara apa yang baik, dan mewujudkan kebaikan itu dalam kehidupan sehari-hari dengan sepenuh hati (Kemendiknas, 2010).

Pendidikan karakter adalah suatu sistem penanaman nilai-nilai karakter kepada anak didik yang meliputi komponen pengetahuan, kesadaran atau kemauan, dan tindakan untuk melaksanakan nilai-nilai tersebut, baik terhadap Tuhan Yang Maha Esa (YME), diri sendiri, sesama, lingkungan, maupun kebangsaan, sehingga menjadi manusia yang berkualitas akhlaknya. Secara lebih rinci, aspek-aspek pendidikan karakter dibagi menjadi 5 jenis karakter utama dan 20 karakter pokok, seperti terdapat pada Tabel 1 (Kemendiknas, 2010). Jenis karakter tersebut, perlu dijabarkan menjadi karakter dalam bentuk lebih operasional, yaitu jenis-jenis etika dan moral dalam kehidupan serta deskriptornya.

Tabel 1. Karakter Utama dan Karakter Pokok

\begin{tabular}{|c|c|}
\hline Karakter Utama & Karakter Pokok \\
\hline \multicolumn{2}{|c|}{ Karakter dalam hubungannya dengan: } \\
\hline A. Tuhan & Religius \\
\hline B. sesama & $\begin{array}{l}\text { Sadar akan hak dan kewajiban diri dan orang lain, patuh pada aturan- } \\
\text { aturan sosial, menghargai karya dan prestasi orang lain, santun, dan } \\
\text { demokratis }\end{array}$ \\
\hline C. lingkungan & Peduli sosial dan lingkungan \\
\hline D. rasa kebangsaan & Nasionalis dan menghargai keberagaman \\
\hline E. diri sendiri & $\begin{array}{l}\text { Jujur, bertanggung jawab, bergaya hidup sehat, disiplin, kerja keras, } \\
\text { percaya diri, berjiwa wirausaha, berpikir, logis, kritis, kreatif, inovatif, } \\
\text { mandiri, rasa ingin tahu, dan cinta ilmu }\end{array}$ \\
\hline
\end{tabular}


Deskriptor nilai/karakter berupa sikap dan/atau perilaku peserta didik. Deskriptor inilah yang dapat dipadukan dalam silabus atau Rencana Pelaksanaan Pembelajaran (RPP). Dalam silabus dan RPP, deskriptor dalam materi pembelajaran, kegiatan pembelajaran, indikator pencapaian kompetensi, dan instrumen hasil pembelajaran. Nilai/karakter dalam bentuk yang lebih operasional, yaitu sikap dan perilaku, ditanam-kan pada peserta didik terutama melalui dimensi kerja ilmiah dan sikap ilmiah. Pelaksanaan hal tersebut dilakukan pada ketiga tahap proses pembelajaran, yaitu perencanaan proses, pelaksanaan proses pembelajaran, dan penilaian hasil proses pembelajaran.

\section{Pentingnya Pendidikan Karakter}

Pada era globalisasi saat ini bangsa Indonesia telah mampu menghasilkan Sumber Daya Manusia (SDM) yang secara kuantitas sudah memadai, namun dari segi kualitas masih sangat perlu ditingkatkan agar dihasilkan SDM yang mampu berkompetisi dengan negara berkembang, bahkan negara maju (Basuki, 2020; Sebastian, 2018). Selain SDM yang demikian, ada satu hal penting yang harus ditekankan, yaitu menghasilkan SDM yang beretika, bermoral, sopan santun, dan mampu berinteraksi dengan masyarakat secara baik, dengan tetap memegang teguh kepribadian bangsa. Dengan kata lain, bangsa Indonesia menginginkan terbentuknya generasi penerus bangsa yang berkarakter dan berkualitas akhlaknya sekaligus cerdas intelektualnya. Banyak contoh anak didik yang cerdas, tetapi kualitas akhlaknya kurang baik, maka mereka tidak dapat diharapkan untuk menjadi generasi penerus yang dapat membangun bangsa (Lonto, 2015).

Berdasarkan penelitian di Harvard University menunjukkan kesuksesan seseorang tidak ditentukan semata-mata oleh pengetahuan dan kemampuan teknis (hard skill), tetapi lebih oleh kemampuan mengelola diri dan orang lain (soft skill) (Dyer et al., 2011). Penelitian ini mengungkapkan, kesuksesan hanya ditentukan sekitar $20 \%$ oleh hard skill dan sisanya $80 \%$ oleh soft skill. Bahkan orang-orang tersukses di dunia dapat berhasil dikarenakan lebih banyak didukung kemampuan soft skill daripada hard skill. Hal ini mengisyaratkan bahwa karakter yang baik sangat penting dimiliki anak didik, karena otak yang hebat tanpa disertai kepribadian yang baik, maka akan sulit diterima di masyarakat nasional maupun internasional.

Dalam pendidikan karakter di sekolah, semua komponen (stakeholders) harus dilibatkan, termasuk komponen-komponen pendidikan itu sendiri, yaitu isi kurikulum, proses pembelajaran dan penilaian, kualitas hubungan, penanganan atau pengelolaan mata pelajaran, pengelolaan sekolah, pelaksanaan aktivitas atau kegiatan ko-kurikuler, pemberdayaan sarana prasarana, pembiayaan, dan etos kerja seluruh warga di lingkungan sekolah. Meskipun guru merupakan ujung tombak pembelajaran di kelas, namun bukan berarti hanya guru yang berkewajiban menanamkan karakter dalam diri anak didik. Semua pihak, baik para pejabat sampai pada tingkat paling bawah satpam, cleaning service, maupun tukang parkirpun harus mampu bersama-sama menciptakan budaya sekolah yang berkarakter sesuai tugas dan kapasitas masing-masing.

Lingkungan sekolah dapat menjadi tempat pendidikan yang baik bagi pertumbuhan karakter anak didik. Semua peristiwa yang terjadi di dalam sekolah dapat diintegrasikan sebagai bahan kajian melalui pendidikan karakter. Dengan demikian, pendidikan karakter merupakan sebuah usaha bersama dari seluruh warga sekolah untuk menciptakan sebuah kultur baru di sekolah, yaitu kultur pendidikan karakter. Secara langsung, lembaga pendidikan dapat menciptakan sebuah pendekatan pendidikan karakter melalui kurikulum, penegakan disiplin, manajemen kelas, maupun melalui program-program pendidikan yang dirancangnya (Zainal, 2011).

\section{Proses Penanaman Karakter}

Berbeda dengan transfer of knowledge, transfer of value atau menanamkan nilai karakter bukanlah pekerjaan yang mudah dilakukan. Penanaman satu jenis karakter (misal karakter kejujuran) memerlukan proses dan waktu yang tidak sebentar. Hal ini karena penanaman karakter memerlukan tahapan-tahapan yang tidak mudah untuk mencapainya dan memerlukan kesabaran. Terlebih bagi seorang guru yang hanya bertemu sekitar $6-7$ jam/hari dengan anak didiknya, tentu memerlukan perencanaan yang matang agar nilai karakter tersebut benar-benar dapat menjadi milik diri anak didik (terinternalisasi atau mendarah daging) dalam diri anak didik.

Secara umum, tahapan-tahapan dalam penanaman karakter meliputi: (1) Belum Terlihat (BT), (2) Mulai Terlihat (MT), (3) Mulai Berkembang (MB), dan (4) Membudaya (M) (Kemendiknas, 2010). Sebagai contoh, ketika seorang guru ingin menanamkan nilai kejujuran dalam mengerjakan ulangan/ujian agar anak didik bekerja sendiri (tidak mencontek), hal itu tidak cukup hanya diawasi dan diberi peringatan dalam bentuk seruan atau peringatan. Pengawasan dan seruan hanya "manjur" ketika mata mampu mengawasi 
gerak-gerik anak didik satu persatu. Pertanyaannya, "mampukah sepasang mata guru mengawasi anak didik sebanyak 30 atau 40 orang?". Tentu jawabannya "tidak", namun dengan kesabaran, nasehat dan peringatan terus-menerus dari seorang guru, maka lama-kelamaan nilai karakter tersebut dapat menjadi milik diri anak didik.

Pada awal-awal penanaman karakter belum terlihat (BT) perubahan karakter, namun secara perlahan akan mulai terlihat (MT), dan seiring berjalannya waktu di dalam jiwa anak didik tersebut akan berproses, sehingga nilai kejujuran akan mulai berkembang (MB). Jika guru tetap gigih dan tak kenal lelah menanamkan karakter tersebut, baik melalui teladan, nasehat, dan peringatan, akhirnya akan berujung pada keberhasilan guru menanamkan karakter kejujuran hingga membudaya (M) dalam diri anak didik. Ciri bahwa karakter tersebut sudah membudaya dalam diri anak didik adalah tanpa adanya pengawasan anak didik tetap menunjukkan kejujuran dalam setiap aktivitasnya (Abdullah, 2019).

Berdasarkan gambaran tersebut, maka sangat disayangkan jika kurikulum saat ini terlalu banyak memberikan muatan nilai karakter yang harus ditanamkan dalam setiap semester. Sejatinya akan lebih efektif jika dalam setiap mapel dalam satu semester hanya diintegrasikan nilai karakter 2 atau 3, sehingga guru benar-benar dapat fokus dalam menanamkannya daripada terlalu banyak nilai karakter dan semuanya hanya sampai tahap MT. Hal ini karena tahapan MT tidak akan sampai membudaya jika tidak diarahkan dan dibimbing lebih lanjut secara serius oleh guru (Wiyono, 2012). Tahap MT dicirikan dengan munculnya karakter tersebut ketika anak didik berada dalam situasi yang tidak memungkinkan untuk menyimpang, artinya anak didik akan tetap mencontek jika keadaan memungkinkan (mencuri kesempatan).

Selama ini hampir sebagian besar guru lebih mementingkan menyelesaikan penyampaian materi pelajaran kepada anak didik, dan sedikit mengambil waktu untuk menanamkan nilai karakter dan budi pekerti. Sudah saatnya sebagai guru mengubah pola pikir (paradigma) dalam mengajar dengan memberikan prioritas pada penanaman nilai karakter, bukan hanya sebagai hiasan (sisipan) dalam pembelajaran. Materi pelajaran yang sekiranya guru berasumsi anak didik dapat mempelajarinya sendiri, maka diserahkan anak didik untuk belajar sendiri, tentu dengan melakukan pengecekan melalui kuis atau sejenisnya untuk mengetahui dipelajari atau tidaknya materi tersebut oleh anak didik. Dengan demikian masih ada waktu yang cukup untuk menasehati dan menampilkan contoh-contoh karakter, baik dalam bingkaian cerita maupun tayangan film pendek yang dapat diperoleh melalui internet.

Melalui proses pendidikan, terutama pendidikan formal di sekolah, peserta didik dapat dibantu untuk mengerti nilai karakter yang diharapkan, dan pelan-pelan membantu mereka untuk melatih dan menjadikan nilai itu sebagai sikap hidupnya. Dengan kata lain dibutuhkan pembiasaan, sehingga nilai itu menjadi nilai yang spontan dijalankan anak (Suparno, 2012). Sekolah mempunyai tanggungjawab besar terhadap pendidikan karakter secara formal, karena anak minimal berada di sekolah $6-7 \mathrm{jam} / \mathrm{hari}$, dan mereka dipercayakan oleh orangtua kepada sekolah untuk dididik dan dibantu berkembang menjadi pribadi yang utuh. Sedangkan secara informal, penanaman karakter menjadi tanggungjawab sepenuhnya orangtua.

\section{Evaluasi Pendidikan Karakter Di Sekolah}

Pembelajaran merupakan suatu sistem yang terdiri atas berbagai komponen yang saling berinteraksi dalam usaha mencapai tujuan pembelajaran yang telah ditetapkan. Setiap proses pembelajaran berlangsung, penting bagi seorang guru mengetahui tercapai tidaknya tujuan tersebut. Hal ini hanya dapat diketahui jika guru melakukan evaluasi, baik evaluasi terhadap proses maupun produk pembelajaran. Hal ini sejalan dengan yang dianjurkan dalam UU RI Guru dan Dosen No. 14/2005 bahwa seorang guru diharuskan memiliki kompetensi pedagogik yang salah satunya adalah kemampuan dalam mengevaluasi. Evaluasi memiliki arti lebih luas daripada penilaian, karena dalam evaluasi sudah tercakup penilaian (Cizek, 2000).

Evaluasi pendidikan karakter di sekolah bertujuan untuk mengukur apakah anak didik sudah memiliki satu atau sekelompok karakter yang ditetapkan oleh sekolah dalam kurun waktu tertentu. Dengan demikian, substansi evaluasi dalam konteks pendidikan karakter merupakan upaya membandingkan perilaku anak didik dengan standar (indikator) karakter yang ditetapkan oleh guru dan/atau sekolah. Proses membandingkan antara perilaku anak dengan indikator karakter dilakukan melalui suatu proses evaluasi. Tujuan evaluasi pendidikan karakter di sekolah adalah untuk mengetahui kemajuan hasil belajar dalam bentuk kepemilikan sejumlah indikator karakter tertentu pada anak didik dalam kurun waktu tertentu; kekurangan dan kelebihan desain pembelajaran yang dibuat oleh guru; dan tingkat efektivitas proses pembelajaran yang dialami oleh anak didik, baik pada setting kelas, sekolah, maupun rumah.

Berdasarkan tujuan evaluasi pendidikan karakter tersebut, maka evaluasi pendidikan karakter tidak terbatas pada pengalaman anak di kelas, tetapi juga pengalaman anak di sekolah dan di rumah. Tentu saja 
dalam hal ini terbatas pada pengalaman belajar anak didik yang didesain secara khusus oleh guru. Dalam hal ini, desain RPP yang dibuat oleh guru harus benar-benar merumuskan pengalaman belajar anak di rumah. Hal ini berarti evaluasi belajar anak di rumah tidak dilakukan jika memang guru tidak mendesain adanya pembelajaran di rumah.

Karakter dikembangkan melalui tahap pengetahuan (knowing), tindakan atau perilaku (acting), menuju kebiasaan (habit). Hal ini berarti, karakter tidak sebatas pada pengetahuan, karakter lebih dalam lagi, menjangkau wilayah emosi dan kebiasaan diri. Dengan demikian diperlukan tiga komponen karakter yang baik (component of good character), yaitu moral knowing (pengetahuan tentang moral), moral feeling (perasaan tentang moral), dan moral action (perbuatan bermoral). Hal ini diperlukan agar peserta didik mampu memahami, merasakan, dan mengajarkan sekaligus nilai-nilai kebajikan (Kemendiknas, 2010; Tanis, 2013).

Karakter merupakan sifat seseorang yang perlu ditumbuhkembangkan melalui proses pendidikan, maka langkah pertama, guru harus mengetahui secara lebih mendalam mengenai substansi suatu karakter, bagaimana memfasilitasi tumbuhkembangnya, dan bagaimana mengevaluasinya. Untuk menjabarkan suatu karakter, maka perlu dikaji definisi isi karakter tersebut. Sebagai contoh, karakter yang ingin dikembangkan sekolah adalah "kedisiplinan". Langkah pertama yang harus dilakukan adalah mendefinisikan atau memberi makna secara khusus yang dimaksud dengan "kedisiplinan". Semakin jelas makna yang terkandung di dalam karakter tersebut, maka semakin mudah untuk menjabarkan indikatornya.

Langkah kedua adalah melakukan elaborasi terhadap substansi makna yang terkandung dalam karakter tersebut melalui suatu hierarki perilaku. Sebagai contoh akan diuraikan karakter tersebut dengan menggunakan format dari Ryan \& Lickona (Komara, 2018), yaitu moral knowing, moral feeling, dan moral action, atau menggunakan moral hierarki perilaku yang dikembangkan oleh Bloom, yaitu kognitif, afektif, dan psikomotor, atau hierarki lainnya. Maksud hierarki ini adalah jika anak didik memahami suatu pengetahuan tentang moral tertentu (moral knowing/kognitif), misal mentaati tata tertib sekolah itu perilaku disiplin, maka hal itu tidak berhenti pada pengetahuan semata. Pengetahuan moral tersebut harus dapat diinternalisasikan ke dalam diri dan jiwa anak didik hingga benar-benar dapat menjadi nilai moral dalam diri dan mengendap dalam jiwanya (moral feeling/afektif). Setelah menjadi nilai moral dalam diri, maka secara otomatis nilai tersebut akan menjiwai ketika tertampilkan dalam bentuk perilaku (moral action/psikomotorik). Penilaian dan evaluasi keberhasilan penanaman karakter kedisiplinan harus ditinjau dari perilaku yang mencirikan kriteria disiplin, misalkan mematuhi tata tertib kelas, mengikuti pelajaran di kelas dengan baik, dan mengerjakan tugas sesuai waktu yang telah ditentukan. Kriteria-kriteria tersebut kemudian dirinci dalam bentuk perilaku yang dapat diamati dalam deskripsi yang jelas dan konkrit.

Setelah merefleksi suatu karakter menjadi suatu hierarki perilaku, maka langkah ketiga adalah menyusun indikator hasil belajar yang harus dikuasai oleh anak sesuai tahap perkembangannya. Perlu menjadi catatan, bahwa yang dinamakan kompetensi mencakup sesuatu yang utuh, yakni meliputi cipta, rasa, dan karsa atau pengetahuan perasaan dan tindakan yang mencakup kognitif, afektif, dan psikomotor.

Langkah keempat adalah menjabarkan indikator karakter menjadi indikator penilaian. Indikator penilaian adalah rumusan mengenai pokok-pokok perilaku yang dapat dijadikan rujukan untuk menilai ketercapaian suatu karakter. Secara umum anak didik terbiasa dinilai sikapnya hanya menggunakan instrumen penilaian sederhana yang dibuat oleh guru. Jarang dijumpai guru yang melakukan penilaian sikap dengan menggunakan instrumen penilaian sikap yang berupa lembar observasi yang disertai rubrik penilaian. Pada umumnya guru hanya menggunakan lembar observasi dengan aspek yang belum terjabarkan ke dalam kriteria-kriteria, sehingga tidak akurat dalam menilai sikap peserta didik. Bahkan ada sebagian guru yang menilai sikap peserta didik tanpa menggunakan instrumen penilaian, hanya mengamati sepintas sikap anak didik ketika proses pembelajaran berlangsung.

Kenyataan menunjukkan ada sebagian guru merasa kesulitan membuat instrumen penilaian sikap, padahal sebenarnya tidak sesulit dan serumit yang dibayangkan. Selama ini guru-guru kurang diperkenalkan mengenai bentuk-bentuk instrumen penilaian sikap, apalagi diperkenalkan cara menyusunnya. Hal ini disebabkan penilaian terhadap aspek afektif diang-gap dapat dilakukan hanya dengan mengamati tingkah laku peserta didik setiap hari, atau cukup dengan melihat catatan pada guru BP. Padahal aspek afektif yang dimaksud tidak semata-mata berkaitan dengan kenakalan dan kedisiplinan, tetapi juga berkaitan dengan berbagai karakter penting yang harus dimiliki peserta didik.

Ketika melakukan penilaian karakter, agar penilaian tersebut objektif dan instrumen penilaiannya dapat digunakan oleh siapa saja dengan pedoman yang pasti, dibutuhkan suatu jabaran kriteria karakter yang dinilai berupa deskripsi dari setiap gradasi kategori (sangat kurang sampai sangat baik) yang disebut 
rubrik penilaian. Rubrik penilaian berupa tabel terdiri atas dimensi (baris) dan skala skor (kolom). Rubrik terdiri atas daftar kriteria yang diwujudkan dengan dimensi-dimensi kinerja, aspek-aspek, atau konsepkonsep yang akan dinilai, dan gradasi mutu, mulai dari tingkat yang paling sempurna sampai dengan tingkat yang paling buruk. Tabel 2 menunujukkan contoh lembar penilaian karakter yang disertai rubrik penilaian untuk karakter kedisiplinan.

Tabel 2. Contoh lembar penilaian karakter yang disertai rubrik penilaian untuk karakter kedisiplinan

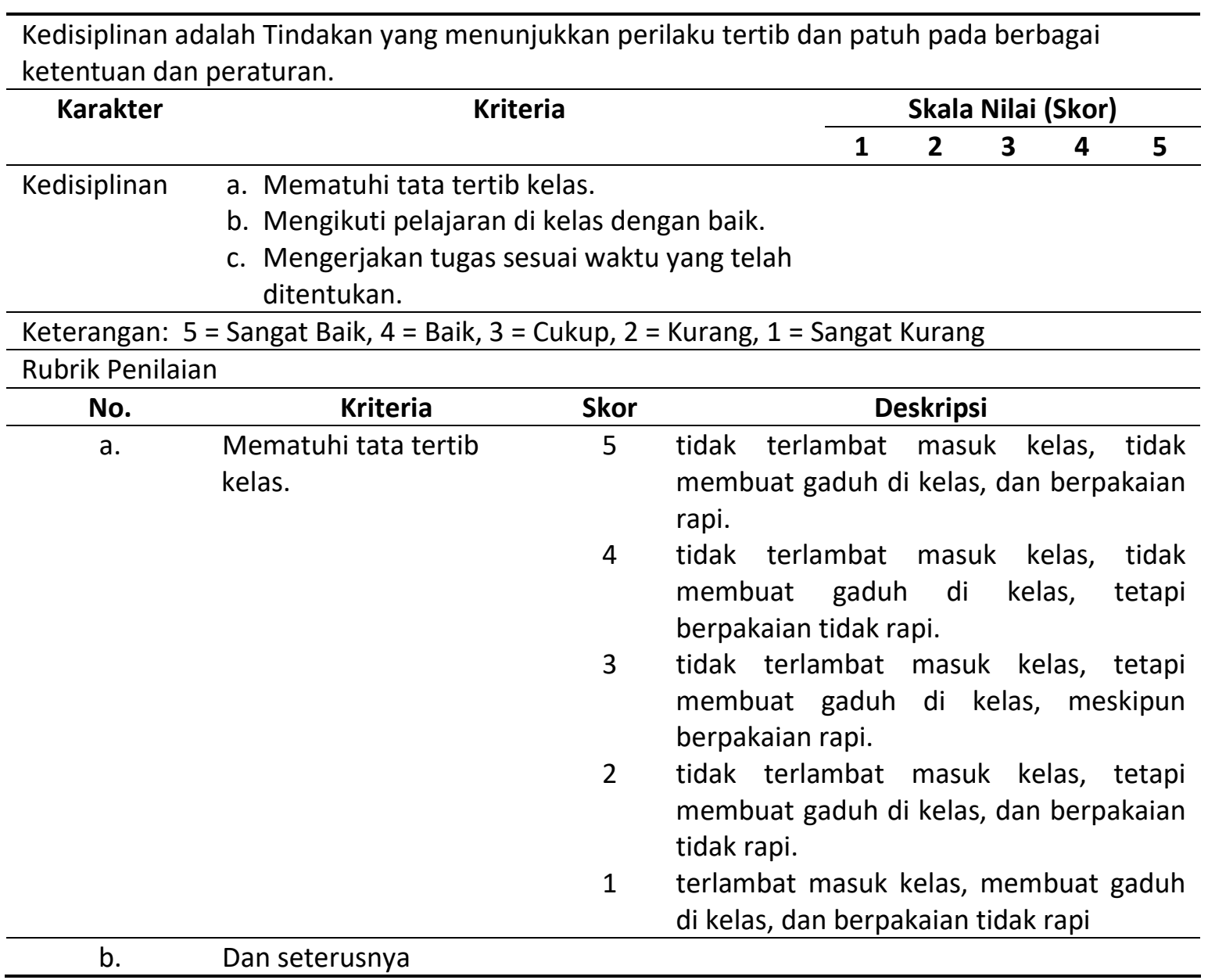

Penilaian karakter dimaksudkan untuk mendeteksi karakter yang terbentuk dalam diri peserta didik melalui pembelajaran yang telah diikutinya. Pembentukan karakter memang tidak dapat terbentuk dalam waktu singkat, akan tetapi indikator perilaku dapat dideteksi secara dini oleh setiap guru. Selain lembar observasi yang disertai rubrik penilaian sebagai pedoman penilaian agar hasilnya konsisten, evaluasi juga dapat dilakukan mengenai berhasil tidaknya pendidikan karakter yang ditanamkan menggunakan berbagai instrumen lainnya, seperti evaluasi diri oleh anak, penilaian teman, catatan anekdot guru, catatan anekdot orang tua, atau jika perlu catatan perkembangan aktivitas anak (psikolog).

Dalam pelaksanaan pendidikan karakter, guru merupakan komponen penting dalam pelaksanaan pendidikan karakter. Ruang kelas merupakan setting utama dalam penilaian pendidikan karakter. Di dalam kelas guru akan melaksanakan proses pembelajaran hingga evaluasi dalam pembelajaran. Evaluasi pendidikan karakter akan dilaksanakan di dalam kelas dengan melakukan pengamatan (observasi) terhadap tingkah laku peserta didik, baik perilaku-nya dengan antar peserta didik maupun dengan guru.

Sekolah merupakan setting kedua dalam penilaian pendidikan karakter, dimana di sekolah peserta didik akan berinteraksi dengan teman-temannya, guru lainnya (termasuk kepala sekolah dan wakil kepala sekolah), pustakawan, laboran, tenaga administrasi sekolah, dan penjaga sekolah. Dalam setting kedua ini, peserta didik akan berhadapan dengan semua warga sekolah dengan jumlah yang lebih besar daripada setting utama (di kelas). Guru akan mengamati bagaimana peserta didik berinteraksi dengan warga sekolah, serta memberikan penilaian berdasarkan aspek karakter apa yang harus dimiliki oleh peserta didik.

Setting evaluasi pendidikan karakter yang terakhir adalah di rumah, dimana di rumah penilaian karakter akan melibatkan peserta didik, orang tuanya (jika masih ada) atau walinya, kakak, dan adiknya (jika ada). Penilaian karakter pada setting ini, guru dapat melakukan kunjungan rumah untuk melakukan pengamatan atau interview (wawancara) dengan orang tua peserta didik. Setting ketiga ini jarang dapat 
dilakukan guru, mengingat keterbatasan waktu yang dimiliki guru. Namun demikian, guru tetap harus berusaha untuk melakukannya jika mendapati ada anak didiknya yang perlu penanganan dalam masalah karakter yang serius.

Penilaian guru terhadap berbagai karakter peserta didik tidak ada maknanya jika tidak ditindaklanjuti dalam bentuk evaluasi terhadap pelaksanaan pendidikan karakter itu sendiri. Sebaliknya evaluasi tanpa diawali penilaian hanyalah sia-sia. Oleh karena itu hasil dari penilaian karakter harus dapat menjadi pertimbangan bagi guru untuk memperbaiki strategi penanaman karakter yang dilakukan, lebih mengintensifkan waktu yang tersedia, dan mencoba melakukan pendekatan emosional yang lebih baik pada peserta didik, termasuk menjalin komunikasi edukatif dan menerapkan pendekatan kasih sayang pada anak didiknya, terutama anak didik yang mengalami masalah serius yang harus segera ditolong. Selain itu hal terpenting yang harus dilakukan guru adalah memberi teladan karakter dalam bentuk perilaku yang terpuji, baik di dalam maupun di luar kelas. Albert Schweitzer dalam Van Fleet (2001) menyatakan "keteladanan bukan merupakan hal yang paling utama dalam kehidupan, tetapi keteladanan satu-satunya hal yang paling penting di dunia ini". Satu keteladanan lebih baik daripada seribu nasehat.

Hal yang perlu diingat bahwa suatu karakter tidak dapat dinilai dalam suatu waktu (one shot evaluation), tetapi harus diobservasi dan diidentifikasi secara terus-menerus dalam keseharian anak, baik di kelas, sekolah, maupun rumah. Menyematkan karakter yang dimiliki peserta didik harus penuh kehatihatian, sebab salah dalam memberi label karakter, dapat berakibat fatal terhadap perkembangan jiwa anak tersebut.

\section{Problematika Pendidikan Karakter Di Sekolah}

Problematika utama yang dihadapi sekolah dalam pelaksanaan evaluasi pendidikan karakter adalah belum adanya pedoman yang operasional dalam melakukan evaluasi pendi-dikan karakter. Sekolah sampai saat ini belum mempunyai model evaluasi pendidikan karakter yang mampu mengevaluasi pendidikan karakter peserta didik secara tepat, efisien dan efektif. Dengan adanya model evaluasi diharapkan sekolah dapat menjaring informasi tentang keadaan karakter peserta didik saat ini, sehingga dapat dilakukan perbaikan dengan tepat.

Prinsip pendidikan karakter adalah mendorong lahirnya anak-anak yang baik, tumbuh dalam karakter yang baik, tumbuh dengan kapasitas dan komitmennya untuk melakukan berbagai hal yang terbaik dan melakukan segalanya dengan benar, dan cenderung memiliki tujuan hidup. Pendidikan karakter yang efektif, ditemukan di lingkungan sekolah yang memungkinkan semua peserta didik menunjukkan potensi mereka untuk mencapai tujuan yang sangat penting (Kemendiknas, 2010; Sani et al., 2020).

Realitas di lapangan menunjukkan bahwa banyak sekolah yang mengatakan bahwa dalam proses pembelajaran sekolah tersebut menggunakan pembelajaran berbasis pendidikan karakter. Namun pada praktiknya belum sepenuhnya memenuhi pencapaian tujuan pendidikan karakter. Meskipun pembelajaran di sekolah sudah merencanakan beberapa instrumen pendidikan karakter, tetapi hanya sebagai wacana, belum sampai pada tingkat pelaksanaan atau aplikasi pendidikan karakter yang diharapkan.

Implementasi pendidikan karakter pada sekolah terdiri atas tiga hal, yaitu penginte-grasian pendidikan karakter dalam (1) semua materi pembelajaran (intrakurikuler), (2) kegiatan ekstrakurikuler, dan (3) melalui budaya sekolah. Namun ternyata strategi ini belum cukup memadai dalam mencapai keberhasilan pendidikan karakter pada anak didik.

Furkan (2013) menyebutkan bahwa faktor penyebab tidak berhasilnya implementasi pendidikan karakter adalah (1) pemikiran bahwa unsur duniawi adalah segalanya, (2) cara pandang ilmu dan teknologi yang keliru, (3) pendidikan karakter tidak menjadi kebutuhan yang penting, (4) sikap atau cara hidup yang individual, (5) sikap ingin mendapatkan segala sesuatunya dengan cepat dan mudah, (6) nilai akademik menjadi ukuran keberhasilan, (8) masuknya nilai dan cara pandang asing yang tidak dapat diantisipasi.

Penelitian Williams (2000) mengidentifikasi permasalahan pendidikan karakter di sekolah, meliputi (1) moralitas adalah masalah pribadi dan harus diajarkan oleh keluarga dan tempat ibadah, bukan sekolah, (2) masalah moral sangat individual, sehingga sekolah tidak mungkin mengajarkan hal tersebut pada anak didik di sekolah, (3) banyak guru tidak memiliki kompetensi untuk mengajarkan moral pada anak didik, (4) moralitas datang dari sumber Illahi yang tidak dapat diajarkan dalam konteks sekuler, (5) pengajaran pendidikan karakter di sekolah akan membuat agama menjadi bagian dari sekolah, (6) waktu yang diperlukan untuk mengajar karakter mengorbankan mata pelajaran yang lebih penting.

Kurikulum pendidikan di Indonesia masih sangat mengutamakan pengembangan kecerdasan rasional (kognitif) dan kurang efektifnya pendidikan nilai dan pembentukan moral. Fakta menunjukkan: (1) anak belum mendapatkan model yang dapat menjadi teladan, (2) pendidikan terlalu menekankan pada 
aspek intelektual, sehingga pembentukan karakter yang baik terabaikan, (3) derasnya informasi yang diterima anak tanpa filter nilai moral menjadikan berkembangnya perilaku antisosial yang membuat pudarnya harkat dan kearifan tradisional (Poerwanti, 2010). Meskipun hanya kasuistik namun banyak peristiwa perilaku guru yang dapat menjatuhkan "nama baik" profesi guru. Sebaliknya banyaknya anak didik yang berperilaku tidak terkendali, pasti yang menjadi "kambing hitam" adalah guru, padahal 70\% hidup anak tersebut ada di luar kendali guru, yaitu di lingkungan sosial dan rumah mereka. Selain itu, pemandangan yang ditangkap dalam setiap sudut sekolah, dimana orangtua berkumpul dan berbincangbincang antar sesama sambil menunggui anaknya pulang, temanya selalu tentang "kehebatan" anak mereka pada aspek intelektual atau kognitif, jarang pembicaraan menyentuh pada "kehebatan" anak mereka pada aspek moral dan keterampilan.

Menurut Huston Pat dalam Poerwanti (2010), kelemahan yang dihadapi dalam penerapan pendidikan karakter pada sekolah adalah tidak adanya penerapan pendidikan karakter secara menyeluruh, melainkan sekadar memenuhi kewajiban mengajar saja, tanpa mengetahui bagaimana seharusnya. Kesimpulannya agar pendidikan karakter berjalan optimal beberapa faktor yang harus diperhatikan diantaranya: (1) sebagian sekolah belum optimal mengevaluasi implementasi pendidikan karakter, (2) belum semua guru dapat dijadikan model implementasi nilai-nilai karakter, (3) sebagian guru belum optimal menanamkan pendidikan karakter dalam pembelajaran, (4) pengintegrasian nilai-nilai karakter dalam budaya sekolah belum berjalan dengan baik, dan (5) belum adanya model evaluasi. Oleh karena itu, Pemerintah (dalam hal ini Kementerian Pendidikan dan Kebudayaan Nasional) perlu berpikir ulang untuk menyeleksi kembali nilai-nilai karakter mana yang harus diutamakan ditanamkan pada peserta didik. Mungkin dalam setiap semester tidak perlu terlalu banyak, dua atau tiga karakter, tetapi guru dapat fokus mengintegrasikan dalam proses pembelajaran, sekaligus dapat menilai secara cermat dan akurat keberhasilan penanaman karakter tersebut, yaitu dengan mengamati sudah membudaya atau belumnya karakter tersebut dalam diri peserta didik, atau bahkan sudah terbentuk habits (kebiasaan) dalam kehidupan sehari-hari mereka. Sedikit tetapi berhasil sampai pada moral action lebih baik daripada banyak tetapi hanya sampai batas moral knowing.

\section{KESIMPULAN}

Pelaksanaan pendidikan karakter telah berjalan di setiap sekolah sejak 10 tahun terakhir, namun hasil pelaksanaan pendidikan karakter tidak dapat diketahui secara pasti. Beberapa faktor indikasi tidak berhasilnya implementasi pendidikan karakter adalah (1) belum adanya model evaluasi pendidikan karakter sebagai pedoman operasional dalam melakukan evaluasi pendidikan karakter peserta didik secara tepat, efisien dan efektif, (2) pendidikan terlalu menekankan pada aspek intelektual sebagai ukuran keberhasilan, sehingga pembentukan karakter yang baik terabaikan, (3) tidak adanya penerapan pendidikan karakter secara menyeluruh, melainkan sekedar memenuhi kewajiban mengajar, tanpa mengetahui bagaimana seharusnya, (4) anak belum mendapatkan model yang dapat menjadi teladan, dan (5) derasnya informasi yang diterima anak tanpa penyaring. Keadaan ini diperparah ketika tidak adanya penerapan pendidikan karakter secara menyeluruh, melainkan sekadar memenuhi kewajiban mengajar saja, tanpa mengetahui bagaimana seharusnya. Beberapa problematika lemahnya evaluasi pendidikan karakter di sekolah yang berhasil diitenfikasi adalah (1) evaluasi implementasi pendidikan karakter belum menjadi prioritas, (2) belum semua guru dapat dijadikan model implementasi nilai-nilai karakter, (3) sebagian guru belum optimal menanamkan pendidikan karakter dalam pembelajaran, (4) pengintegrasian nilai-nilai karakter dalam budaya sekolah belum berjalan dengan baik, dan (5) belum adanya model evaluasi. Solusi dari problematika diatas yang ditawarkan adalah memlalui langkah-langkah: (1) mendefinisikan atau memberi makna secara khusus pada karakter yang akan dicapai, (2) elaborasi terhadap substansi makna yang terkandung dalam karakter tersebut melalui suatu hierarki perilaku: moral knowing, moral feeling, dan moral action, (3) menyusun indikator hasil belajar yang harus dikuasai oleh anak sesuai tahap perkembangannya, (4) menjabarkan indikator karakter menjadi indikator penilaian dalam bentuk rubrik.

\section{DAFTAR PUSTAKA}

Abdullah, D. (2019). Pengembangan Perangkat Pembelajaran Berkarakter Pada Mata Kuliah Kimia Dasar. Binomial, 2(1), 33-53.

Basuki, R. (2020). Conceptual Difficulties Experienced by First Year Undergraduate Chemistry Students to 
Assigning Oxidation Number: A Case Study Of High School Chemistry Textbooks. Indonesian Journal of Chemistry, 1(223-236). https://doi.org/10.22146/ijc.36695

Cizek, G. J. (2000). Pockets of Resistance in the Assessment Revolution. Educational Measurement: Issues and Practice, 19(2), 16-23.

Darmayanti, S. E., \& Wibowo, U. B. (2014). Evaluasi program pendidikan karakter di sekolah dasar Kabupaten Kulon Progo. Jurnal Prima Edukasia, 2(2), 223-234.

Dyer, J. H., Gregersen, H. B., \& Christensen, C. M. (2011). Five Discovery Skills that Distinguish Great Innovators. Working Knowledge, Harvard Business School.

Fakhruddin, A. (2014). Urgensi Pendidikan Nilai Untuk Memecahkan Problematika Nilai dalam Konteks Pendidikan Persekolahan. Jurnal Pendidikan Agama Islam-Ta'lim, 12(1), 79-96.

Furkan, N. (2013). Pendidikan Karakter melalui budaya sekolah. Yogyakarta: Magnum Pustaka Utama.

Guntur, M., \& Aslinda, A. (2017). Implementasi Kebijakan Pendidikan Karakter terhadap Pengaruh Globalisasi. Prosiding Seminar Nasional Himpunan Sarjana IImu-IImu Sosial, 2, 231-238.

Hanum, A., \& Annas, A. (2019). Penggunaan Kurikulum Serta Penanaman Nilai dan Spiritual Siswa. Indonesian Journal of Learning Education and Counseling, 1(2), 160-168.

KBBI. (2008). Departemen Pendidikan Nasional. Jakarta: Gramedia Pustaka Utama.

Kemendiknas. (2010). Pendidikan Karakter di Sekolah Menengah Pertama. Depdiknas.

Komara, E. (2018). Penguatan Pendidikan Karakter dan Pembelajaran Abad 21. Sipatahoenan, 4(1).

Lonto, A. L. (2015). Pengembangan model pendidikan karakter berbasis nilai sosio-kultural pada siswa SMA di Minahasa. Mimbar: Jurnal Sosial Dan Pembangunan, 31(2), 319-327.

Munawwaroh, A. (2019). Keteladanan Sebagai Metode Pendidikan Karakter. Jurnal Penelitian Pendidikan Islam,[SL], 7(2), 141-156.

Palunga, R., \& Marzuki, M. (2017). Peran Guru dalam Pengembangan Karakter Peserta Dldik di Sekolah Menengah Pertama Negeri 2 Depok Sleman. Jurnal Pendidikan Karakter, 7(1).

Poerwanti, E. (2010). Pengembangan Instrumen Asesmen Pendidikan Di Taman Kanak-Kanak. Universitas Negeri Yogyakarta.

Purandina, I. P. Y., \& Winaya, I. M. A. (2020). Pendidikan Karakter di Lingkungan Keluarga Selama Pembelajaran Jarak Jauh pada Masa Pandemi COVID-19. Cetta: Jurnal IImu Pendidikan, 3(2), 270290.

Ritonga, M. K., Hasibuan, M. N. S., \& Siregar, M. (2020). Analisis Terhadap Mahasiswa Prodi Ppkn Stkip Labuhanbatu Dalam Studi Kasus Kunjungan Perpustakaan Dan Aplikasinya Pada Penerapan Karakter Semangat Kebangsaan Tahun 2019. Jurnal Education and Development, 8(3), 42.

Ryan, K., \& Lickona, T. (1992). Character development in schools and beyond (Vol. 3). CRVP.

Salirawati, D. (2012). Percaya diri, keingintahuan, dan berjiwa wirausaha: tiga karakter penting bagi peserta didik. Jurnal Pendidikan Karakter, 2(2), 213-224.

Sani, M. M. R., Meha, A. M., \& Nenotek, S. A. (2020). Penerapan Model Siklus Belajar 5E Untuk Meningkatkan Kemampuan Berpikir Tingkat Tinggi (HOTS) Siswa di SMP Adhyaksa 2 Kupang Tahun Ajaran 2018/2019. Jurnal Sains Dan Edukasi Sains, 3(1), 15-23. 
Sebastian, E. (2018). Peningkatan Peranan SDM Pertahanan Nasional Guna Menghadapi Perang Generasi Keempat. Jurnal Pertahanan \& Bela Negara, 5(1), 109-128.

Soedarsono, S. (2013). Karakter Mengenal Bangsa Gelap Menuju Terang. Elex Media Komputindo.

Sukmadinata, N. S. (2005). Metode penelitian pendidikan. PT Remaja Rosdakarya.

Sulistiani, S., \& Sukarman. (2020). Membangun Karakter Berbasis Budaya Jawa Pada Era Revolusi Industri 4.0, Revolusi Society 5.0, Dan "Merdeka Belajar." Prosiding Seminar Nasional 2020 LP3M Universitas Negeri Surabaya, 2.

Suparno, P. (2012). Peran Pendidikan dan Penelitian Terhadap Pembangunan karakter Bangsa. Disajikan Pada Seminar Nasional Yang Diselengarakan Oleh LPPM UNY, Tanggal 11--12 Mei 2012.

Tanis, H. (2013). Pentingnya Pendidikan Character Building dalam Membentuk Kepribadian Mahasiswa. Humaniora, 4(2), 1212-1219.

Van Fleet, J. K. (2001). Menggali dan mengembangkan kekuatan tersembunyi di dalam diri. Jakarta: Mitra Utama.

Williams, M. M. (2000). Models of character education: Perspectives and developmental issues. The Journal of Humanistic Counseling, Education and Development, 39(1), 32-40.

Wiyono, H. (2012). Pendidikan karakter dalam bingkai pembelajaran di sekolah. CIVIS, 2(2), 1-18.

Yuliana, E. D. (2000). Pentingnya pendidikan karakter bangsa guna merevitalisasi ketahanan bangsa. Buletin Udayana Mengabdi, 9(2).

Zainal, A. (2011). Pendidikan Karakter: Membangun Perilaku Positif Anak Bangsa. Bandung: Yrama Widya.

Zuchdi, D. (2010). Pengembangan model pendidikan karakter terintegrasi dalam pembelajaran bidang studi di sekolah dasar. Jurnal Cakrawala Pendidikan, 1(3), 1-12. 